\title{
PENERAPAN MODEL PENGAJARAN LANGSUNG UNTUK MENINGKATKAN PRESTASI BELAJAR SISWA PADA MATA DIKLAT MENYUSUN LAPORAN KEUANGAN PERUSAHAAN DAGANG
}

\author{
Angela Merici Fina Indriani \\ SMK Negeri 1 Pamekasan \\ xie_sunset@yahoo.com
}

\begin{abstract}
The purpose of this research is to apply direct instruction model to improve learning achievement. This research is conducted in two cyles. This research is a classroom action research. The subject of this research were students in fianancial subject grade XI in SMKN 1 Pamekasan. The results showed that application of the direct instruction model can improve student achievement to prepare financial statements on the trading companies at financial subject in SMKN 1 Pamekasan
\end{abstract}

Keywords: Direct Instruction Model, Classroom Research Action, Learning Achievement

\begin{abstract}
Abstrak: Tujuan penelitian adalah untuk mengetahui penerapan model pengajaran langsung untuk meningkatkan prestasi belajar siswa. Penelitian dilakukan dalam dua siklus. Penelitian ini merupakan penelitian tindakan kelas. Subyek penelitian adalah siswa kelas XI Keuangan 2 SMK Negeri 1 Pamekasan. Hasil penelitian menunjukkan bahwa penerapan model pengajaran langsung dapat meningkatkan prestasi belajar siswa pada mata diklat menyusun laporan keuangan perusahaan dagang pada siswa kelas XI Keuangan 2 SMKN 1 Pamekasan.
\end{abstract}

Kata Kunci: Model Pengajaran Langsung, Penelitian Tindakan Kelas, Prestasi Belajar

Pendidikan memegang peranan penting dalam mempersiapkan generasi muda bangsa agar mampu menghadapi dan mengatasi segala tantangan yang terjadi pada era globalisasi saat ini. Upaya yang bisa dilakukan agar tujuan tersebut terwujud adalah dengan meningkatkan mutu pendidikan. Berbagai usaha telah dilakukan untuk meningkatkan mutu pendidikan antara lain pelatihan keterampilan dan peningkatan kualifikasi guru, penyempurnaan kurikulum, pengadaan buku dan alat pengajaran, perbaikan sarana serta prasarana. Mutu pendidikan akan tercapai jika proses belajar mengajar efisien dan efektif bagi tercapainya pengetahuan dan keterampilan sehingga menghasilkan lulusan siswa yang sesuai dengan tuntutan zaman. 
Disadari atau tidak, mutu pendidikan ditentukan oleh kualitas pembelajaran yang ditandai dengan adanya interaksi antar siswa, antara siswa dengan guru, serta siswa dengan sumber belajar. Interaksi ini sangat berpengaruh dalam keaktifan siswa dalam proses belajar mengajar. Kemampuan belajar siswa, penentuan metode mengajar yang digunakan guru serta menyusun strategi belajar mengajar yang sesuai dengan prinsip belajar dan pembelajaran perlu diperhatikan agar proses belajar-mengajar efektif dan efisien.

Kenyataan yang terjadi di lapangan, pembelajaran diberikan dengan menyampaikan materi sebanyak-banyaknya sesuai dengan target kurikulum tanpa memberikan kesempatan yang luas bagi siswa untuk berlatih, sehingga hanya beberapa siswa yang bisa memahami pengajaran yang diberikan. Pengajaran awal yang diberikan pada siswa XI Keuangan 2 menggunakan metode ceramah, dan metode tersebut kurang efektif untuk siswa SMK yang menitikberatkan pada praktek.

Berdasarkan observasi awal yang dilakukan, yaitu selama proses pembelajaran membukukan jurnal penyesuaian, menunjukkan bahwa 84\% siswa XI Keuangan 2 masih memiliki kesulitan dalam mata diklat tersebut. Hal ini ditunjukkan dengan masih banyak siswa yang memiliki nilai di bawah Kriteria Ketuntasan Minimal ( KKM ) yang telah ditetapkan, yaitu 75. Observasi awal menunjukkan data bahwa hanya $16 \%$ siswa memiliki nilai di atas KKM, dan ada 66\% siswa yang memiliki nilai di bawah 50. Data tersebut menunjukkan bahwa siswa kelas XI Keuangan 2 belum kompeten untuk praktek kerja industri. Hal ini tidak sejalan dengan tujuan pendidikan menengah kejuruan yang mengharapkan agar lulusan SMK langsung siap kerja.

Kurikulum SMK lebih menitikberatkan pada penguasaan praktek di lapangan, sesuai dengan Peraturan Pemerintah No. 29 Tahun 1990 tentang Pendidikan Menengah Bab 1 Pasal 1 Ayat 3, bahwa "Pendidikan menengah kejuruan adalah pendidikan pada jenjang menengah yang mengutamakan pengembangan kemampuan siswa untuk melaksanakan jenis pekerjaan tertentu." Dan pasal 3 ayat 2, bahwa "Pendidikan menengah kejuruan mengutamakan penyiapan siswa untuk memasuki lapangan kerja serta mengembangkan sikap profesional."

Perubahan model pembelajaran sangat diperlukan demi tercapainya tujuan pendidikan menengah kejuruan tersebut. Model pembelajaran adalah suatu perencanaan atau suatu pola yang digunakan sebagai pedoman dalam merencanakan pembelajaran di 
kelas atau pembelajaran dalam tutorial dan untuk menentukan perangkat-perangkat pembelajaran termasuk di dalamnya buku-buku, film, komputer, dan lain-lain. Setiap model pembelajaran mengarahkan guru kedalam mendesain pelajaran untuk membantu siswa sedemikian rupa sehingga tujuan pembelajaran tercapai (Joyce dalam Trianto, 2009).

Trianto (2009) mengemukakan maksud dari model pembelajaran adalah kerangka konseptual yang melukiskan prosedur yang sistematis dalam mengorganisasikan pengalaman belajar untuk mencapai tujuan belajar tertentu dan berfungsi sebagai pedoman bagi para perancang pembelajaran dan para pengajar dalam merencanakan aktivitas belajar mengajar.

Model pembelajaran yang dipilih dalam penelitian ini adalah model pengajaran langsung ( direct instruction). Model direct intruction merupakan suatu pendekatan mengajar yang dapat membantu siswa dalam mempelajari keterampilan dasar dan memperoleh informasi yang dapat diajarkan selangkah demi selangkah. Pendekatan mengajar ini sering disebut Model Pengajaran Langsung (Kardi dan Nur, dalam penelitian tindakan kelas.blogspot.com,2009).

Keterampilan dasar diperlukan siswa untuk lebih memahami konsep dasar Akuntansi yang diajarkan. Selain itu juga dengan latihan keterampilan siswa diajak untuk berperan aktif dalam kegiatan belajar mengajar sehingga saat pelajaran siswa tidak hanya duduk, diam, dan mendengarkan lagi. Pada model pengajaran langsung, informasi diajarkan selangkah demi selangkah dengan harapan siswa dapat menguasai keterampilan secara menyeluruh.

Model pengajaran langsung memiliki empat cirri khusus (Kardidan Nur dalam Trianto, 2009), yaitu: (1) rasional teoretislogis yang disusun oleh para pencipta atau pengembangnya; (2) landasan pemikiran tentang apa dan bagaimana siswa belajar (tujuan pembelajaran yang akan dicapai); (3) tingkah laku mengajar yang diperlukan agar model tersebut dapat dilaksanakan dengan berhasil; (4) lingkungan belajar yang diperlukan agar tujuan pembelajaran itu dapat tercapai.

Pada model pengajaran langsung seorang guru harus memiliki pemahaman atau keahlian memberi instruksi yang jelas dan teratur sehingga siswa memahami informasi yang diberikan (www.educationbug.org,2009). Model pengajaran langsung memang masih teacher centered, tetapi guru tidak hanya memberikan materi dengan cara 
ceramah. Guru memberikan materi sambil mengajarkan tahapan-tahapan pengetahuan sehingga siswa tetap dilibatkan dalam proses pengajaran. Alasan pemilihan model ini adalah agar siswa tidak terlalu kaget dengan perubahan metode pengajaran dari metode ceramah ke model pengajaran langsung. Perubahan model pengajaran tersebut diharapkan mampu meningkatkan prestasi belajar siswa, sehingga ada perubahan yang signifikan dari data awal observasi.

Pada model pengajaran langsung terdapat lima fase yang sangat penting yaitu: (1) Menyampaikan tujuan dan mempersiapkan siswa; guru menjelaskan TPK, informasi materi pelajaran, pentingnya pelajaran, mempersiapkan siswa untuk belajar; (2) Mendemonstrasikan pengetahuan atau keterampilan; guru mendemonstrasikan keterampilan dengan benar, atau menyajikan informasi tahap demi tahap; (3) Membimbing pelatihan; guru merencanakan dan memberi bimbingan pelatihan awal; (4) Mengecek pemahaman dan memberikan umpan balik; mengecek apakah siswa telah berhasil melakukan tugas dengan baik dan memberi umpan balik; (5) Memberikan kesempatan untuk pelatihan lanjutan; guru mempersiapkan kesempatan melakukan pelatihan lanjutan, dengan perhatian khusus pada penerapan kepada situasi lebih kompleks dalam kehidupan sehari-hari.

Trianto (2009) mengatakan bahwa belajar diartikan sebagai perubahan pada individu yang terjadi melalui pengalaman dan bukan karena pertumbuhan atau perkembangan tubuhnya atau karakteristik seseorang sejak lahir. Proses belajar terjadi melalui banyak cara, baik disengaja maupun tidak disengaja akan berlangsung sepanjang waktu dan menuju pada suatu perubahan pada diri siswa. Perubahan yang dimaksud adalah perubahan perilaku tetap berupa pengetahuan, pemahaman, keterampilan, dan kebiasaan baru yang diperoleh siswa. Sedangkan pengalaman merupakan interaksi antara siswa dengan lingkungan sebagai sumber belajar. Jadi, belajar diartikan sebagai proses perubahan perilaku tetap dari belum tahu menjadi tahu, dari tidak paham menjadi paham, dari kurang terampil menjadi terampil, dan dari kebiasaan lama menjadi kebiasaan baru, serta bermanfaat bagi lingkungan maupun individu itu sendiri.

Prestasi belajar merupakan hal yang tidak dapat dipisahkan dari kegiatan belajar, karena kegiatan belajar merupakan proses, sedangkan prestasi merupakan hasil dari proses belajar. Selanjutnya Winkel (dalam sunartombs.wordpress.com, 2009) 
mengatakan bahwa prestasi belajar adalah suatu bukti keberhasilan belajar atau kemampuan seseorang siswa dalam melakukan kegiatan belajarnya sesuai dengan bobot yang dicapainya. Prestasi belajar seseorang sesuai dengan tingkat keberhasilan sesuatu dalam mempelajari materi pelajaran yang dinyatakan dalam bentuk nilai atau rapor setiap bidang studi setelah mengalami proses belajar mengajar. Prestasi belajar siswa dapat diketahui setelah diadakan evaluasi. Hasil dari evaluasi dapat memperlihatkan tentang tinggi atau rendahnya prestasi belajar siswa (sunartombs.wordpress.com, 2009).

Berdasarkan fenomena tersebut maka peneliti tertarik untuk melakukan Penelitian Tindakan Kelas (PTK) dengan judul Penerapan Model Pengajaran Langsung untuk Meningkatkan Prestasi Belajar Siswa pada Mata Diklat Menyusun Laporan Keuangan Perusahaan Dagang di Kelas XI Keuangan 2 SMK Negeri 1 Pamekasan.

\section{METODE}

Jenis penelitian ini termasuk dalam penelitian tindakan kelas ( PTK). Menurut Wiriaatmadja (2006:11) mengemukakan bahwa Penelitian Tindakan Kelas adalah penelitian yang mengkombinasikan prosedur penelitian dengan tindakan substantif, suatu tindakan yang dilakukan dalam disiplin inkuiri, atau suatu usaha seseorang untuk memahami apa yang sedang terjadi, sambil terlibat dalam sebuah proses perbaikan dan perubahan. Tindakan perbaikan yang dilakukan adalah merubah metode pengajaran dari yang semula metode ceramah menjadi model pengajaran langsung. Perbedaan PTK dibandingkan dengan penelitian yang lain terletak pada pelaksanaan kegiatan penelitian yang dilakukan. Penelitian ini dilakukan dalam dua siklus tindakan yang terdiri dari empat tahapan, yaitu rencana (planning), pelaksanaan tindakan (action), observasi (observation), dan refleksi (reflection). 
Secara umum alur pelaksanaan tindakan dalam penelitian tindakan kelas ini dapat digambarkan sebagai berikut:

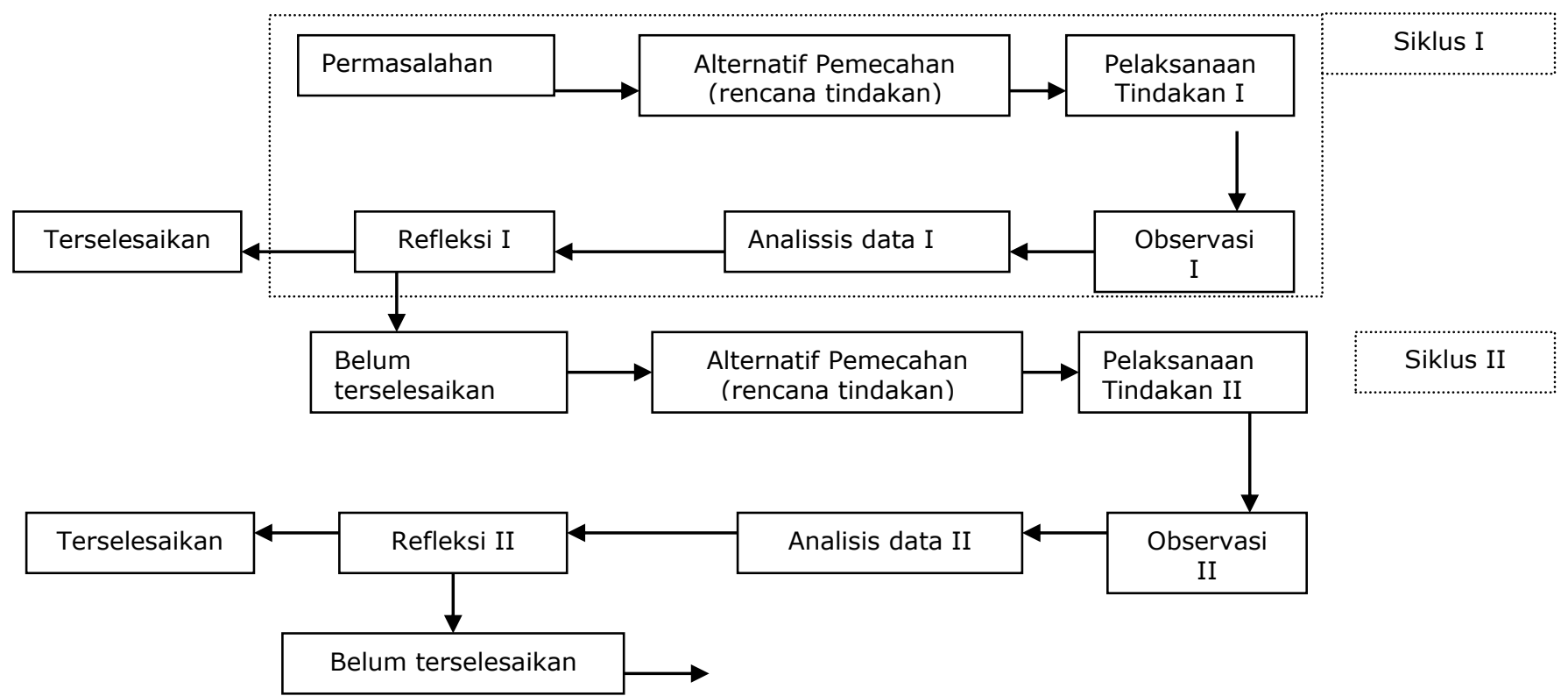

Gambar 1. Alur Tindakan dalam PTK

( Sumber: Tim Pelatihan Proyek PGSM, 1992: 27)

Dalam penelitian ini, guru merencanakan, melaksanakan, menyimpulkan data, menganalisis data, menafsirkan data, dan melaporkan hasil penelitian. Proses pengumpulan data dilaksanakan selama proses belajar berlangsung di kelas pada saat penelitian tindakan kelas dilaksanakan, yaitu selama pembelajaran pada semester 2 tahun pelajaran 2011/2012 dari bulan Maret hingga bulan Mei 2012.

Subyek penelitian ini adalah siswa kelas XI Keuangan 2 SMKN 1 Pamekasan sebanyak 32 siswa. Subyek dipilih karena guru juga bertindak sebagai guru mata diklat menyusun laporan keuangan perusahaan dagang pada kelas tersebut. Instrumen yang digunakan dalam penelitian ini adalah hasil ulangan harian 1 siswa sebagai data awal, RPP, pedoman wawancara dengan siswa, dan catatan atau jurnal mengajar guru.

Penelitian ini menggunakan model penelitian tindakan kelas dengan dua siklus yang disesuaikan dengan sintaks atau tahapan dalam model pengajaran langsung yang meliputi lima fase, yaitu menyampaikan tujuan pembelajaran dan memersiapkan siswa, mendemonstrasikan pengetahuan atau keterampilan, membimbing pelatihan, mengecek pemahaman dan memberikan umpan balik, memberikan kesempatan untuk pelatihan 
lanjutan. Tiap-tiap siklus terdiri dari kegiatan; (1) perencanaan, (2) pelaksanaan, (3) pengamatan, dan (4) refleksi. Perencanaan merupakan kegiatan awal untuk memulai PTK. Perencanaan yang dilakukan dalam PTK ini adalah: menyiapkan RPP dengan model pengajaran langsung, menyiapkan media pembelajaran, menyiapkan LKS, dan menyiapkan lembar evaluasi; (2) Pelaksanaan Tindakan; Pelaksanaan tindakan merupakan kegiatan memberikan pelajaran akuntansi dengan mata diklat menyusun laporan keuangan perusahaan dagang sesuai dengan RPP yang telah disiapkan dengan model pengajaran langsung; (3) Pengamatan; Kegiatan pengamatan dilakukan dengan mengamati sejauh mana model pengajaran langsung dapat meningkatkan prestasi belajar siswa. Pengamatan dilakukan berdasarkan hasil ulangan harian berikutnya; (4) Refleksi; Refleksi dilakukan untuk meninjau keberhasilan dan kelemahan yang terjadi pada siklus yang sedang dilaksanakan serta hambatan yang ditemui dalam melaksanakan model pengajaran langsung. Hasil refleksi digunakan untuk meningkatkan kualitas pengajaran pada siklus selanjutnya. Indikator keberhasilan penelitian adalah jika terjadi peningkatan nilai siswa.

\section{HASIL DAN PEMBAHASAN}

Pembelajaran dalam penelitian ini menggunakan model pengajaran langsung, yaitu model pengajaran dimana siswa mempelajari keterampilan dasar atau pengetahuan yang diajarkan selangkah demi selangkah (Arends dalam penelitian tindakan kelas.blogspot.com, 2009). Materi yang diberikan yaitu mata diklat menyusun laporan keuangan perusahaan dagang. Pada siklus pertama, materi yang diberikan yaitu mengidentifikasi data yang digunakan dalam penyusunan laporan keuangan, dalam hal ini adalah penggunaan neraca lajur.

Kegiatan PTK dimulai dengan tahap perencanaan. Pada tahap perencanaan, guru mempersiapkan hal-hal sebagai berikut; (1) Menyiapkan Rencana Program Pembelajaran (RPP) tentang Menyusun Neraca Lajur dengan menerapkan model pengajaran langsung; (2) Menyiapkan materi yang disimpan dalam file laptop untuk mempermudah pengajaran di kelas; (3) Menyiapkan dan memperbanyak Lembar Kerja Siswa (LKS) Menyusun Neraca Lajur

Pada tahap pelaksanaan tindakan, guru mengajar di kelas dengan mengacu pada RPP yang telah dipersiapkan sebelumnya. Setiap pelaksanaan tindakan masing-masing 
siklus menggunakan model pengajaran langsung (Direct Instruction). Pembelajaran dilakukan sesuai dengan sintaks atau tahapan model pengajaran langsung.

Fase pertama yaitu menyampaikan tujuan pembelajaran dan memersiapkan siswa untuk belajar akuntansi. Guru menyampaikan tujuan yang ingin dicapai dalam pembelajaran untuk meningkatkan rasa ingin tahu siswa terhadap materi pelajaran yang akan mereka terima, yaitu siswa mampu menyusun neraca lajur. Guru juga menginformasikan kepada siswa bahwa selama pembahasan neraca lajur, guru menggunakan model pengajaran langsung. Informasi ini disampaikan supaya siswa lebih termotivasi dalam mengikuti pelajaran karena mereka akan menghadapi sesuatu yang baru, baik dari segi materi maupun cara belajar. Pembelajaran dimulai dengan tanya jawab sekilas tentang materi sebelumnya, yaitu ayat jurnal penyesuaian dan keterkaitan materi yang akan diajarkan dengan materi sebelumnya.

Fase kedua yaitu mendemonstrasikan pengetahuan dan keterampilan. Guru dengan bantuan laptop dan LCD menampilkan sheet neraca lajur. Guru juga telah menyiapkan sheet neraca saldo dan sheet ayat jurnal penyesuaian yang telah dibahas pada pertemuan sebelumnya. Hal ini dilakukan agar siswa paham tentang keterkaitan antara materi neraca lajur dengan materi ayat jurnal penyesuaian. Guru mendemonstrasikan pengisian neraca lajur secara runtut, yaitu mulai memindahkan nomor dan nama akun dari neraca saldo ke kolom nomor dan nama akun di neraca lajur. Siswa diminta untuk mengisi neraca lajur dalam kolom yang telah disiapkan sebelumnya sesuai dengan demonstrasi yang dilakukan guru. Setelah itu, guru mendemonstrasikan pemindahan saldo masing - masing akun dari neraca saldo ke kolom neraca saldo di neraca lajur, kemudian diikuti oleh siswa dalam lembar kerjanya masing-masing. Setelah selesai memindahkan saldo, guru mendemonstrasikan pemindahan ayat jurnal penyesuaian dari jurnal penyesuaian yang telah dibuat pada pertemuan sebelumnya ke dalam neraca lajur kolom AJP, kemudian guru juga mendemonstrasikan pengisian kolom NSSD, kolom laba/rugi dan kolom neraca. Setiap selesai melakukan satu demonstrasi, guru akan memberikan bimbingan kepada siswa untuk mengikuti langkah pekerjaan guru, dan guru berkeliling untuk memeriksa pekerjaan siswa sebagai pelaksanaan dari fase ketiga.

Fase keempat yaitu mengecek pemahaman dan memberikan umpan balik, sehingga pada fase ini guru memberikan tugas tentang materi neraca lajur dan 
memanggil siswa secara acak untuk menyelesaikan neraca lajur yang tersaji pada papan. Setelah siswa yang terpilih mengerjakan soal yang diberikan, guru memberikan pertanyaan secara lisan untuk lebih mengecek pemahaman siswa. Pada fase kelima, yaitu guru memberikan kesempatan untuk pelatihan lanjutan dengan memberikan pekerjaan rumah kepada siswa. Setelah semua fase pada model pengajaran langsung diterapkan, guru melaksanakan evaluasi pembelajaran untuk mengetahui keefektifan model pengajaran langsung pada pembelajaran di kelas XI Keuangan 2.

Observasi dilaksanakan oleh guru selaku guru bidang studi. Pada kegiatan observasi, guru mengamati kemampuan siswa dalam menangkap pelajaran. Hasil observasi yang dilaksanakan oleh guru terhadap siswa adalah sebagai berikut; (1) Beberapa siswa kurang fokus terhadap pelajaran sehingga kurang memahami instruksi dari guru; (2) Siswa yang pintar dan "cerewet" lebih mendominasi dari yang lain; (3) Beberapa siswa selalu mengobrol di kelas dan tidur-tiduran selama pelajaran sehingga menunjukkan bahwa mereka kurang memiliki motivasi dalam belajar.

Refleksi dilaksanakan setelah diadakan pengamatan selama pembelajaran dan hasil tes belajar siswa. Hasil dari refleksi yang dilaksanakan pada siklus I adalah sebagai berikut: (1) Guru sebaiknya beberapa kali berjalan di antara siswa pada saat kegiatan belajar mengajar, sehingga dapat mengurangi ketidakseriusan siswa yang sering mengobrol; (2) Guru kurang terampil dalam menyampaikan kalimat yang sederhana, namun mudah dimengerti siswa; (3) Usaha guru memotivasi siswa untuk aktif di kelas masih kurang; (4) Perlu ada penambahan waktu atau pengurangan jumlah soal dalam tes evaluasi; (5) Hasil tes belajar pada siklus I menunjukkan 6 siswa dari 32 siswa (19\%) memiliki nilai di atas 75, 11 siswa (34\%) memiliki nilai antara 70 - 75, 12 siswa (38\%) memiliki nilai antara 60 - 69, 3 siswa (9\%) memiliki nilai antara 50 -59, dan tidak ada siswa yang memiliki nilai di bawah 50; (6) Pelaksanaan siklus I secara umum cukup baik karena dapat meningkatkan prestasi belajar siswa yang sangat bermakna walaupun belum maksimal. Oleh karena itu, kegiatan PTK akan dilanjutkan pada siklus II dengan materi menyajikan laporan keuangan perusahaan dagang.

Siklus II dimulai dengan tahap perencanaan. Pada tahap perencanaan, guru mempersiapkan hal-hal sebagai berikut: (1) Menyiapkan Rencana Program Pembelajaran (RPP) tentang Menyusun Laporan Keuangan Perusahaan Dagang dengan menerapkan model pengajaran langsung; (2) Menyiapkan materi yang disimpan dalam 
file laptop untuk mempermudah pengajaran di kelas; (3) Menyiapkan dan memperbanyak Lembar Kerja Siswa (LKS) Menyusun Laporan Keuangan Perusahaan Dagang.

Pada tahap pelaksanaan tindakan pada siklus II, guru mengajar di kelas dengan mengacu pada RPP yang telah dipersiapkan sebelumnya yang menggunakan model pengajaran langsung (Direct Instruction). Pada materi ini siswa diajarkan cara membuat laporan keuangan perusahaan. Laporan yang perlu dibuat hanya empat, yaitu laporan laba rugi, laporan laba ditahan, neraca dan laporan arus kas. Guru menggunakan soal dari materi sebelumnya agar siswa memahami yang dinamakan siklus akuntansi. Neraca lajur yang telah dijelaskan sebelumnya pada siklus pertama menjadi panduan dalam menyusun laporan keuangan perusahaan dagang. Guru menyajikan neraca lajur yang telah terisi dan menjelaskan secara bertahap format laporan keuangan.

Pada siklus kedua ini, guru juga menggunakan LCD dan laptop untuk mempermudah penyampaian materi kepada siswa. Penyampaian tujuan pengajaran menjadi pembuka sesuai dengan fase pertama dalam model pengajaran langsung. Fase kedua yaitu mendemonstrasikan pengetahuan atau keterampilan. Guru telah menyiapkan neraca lajur dan format kosong (hanya kolom saja) laporan keuangan dan dibagikan pada siswa. Pada neraca lajur telah terdapat kolom laba rugi dan kolom neraca. Guru mendemonstrasikan pengisian format kosong laporan keuangan dari data yang terdapat pada neraca lajur sambil tanya jawab dengan siswa dan menyuruh siswa mengikuti contoh pekerjaan yang telah dilakukan oleh guru. Setiap selesai memberikan satu contoh, guru akan berkeliling mengecek pekerjaan siswa sambil memberikan bimbingan sebagai implementasi fase ketiga.

Fase keempat yaitu mengecek pemahaman dan memberikan umpan balik, sehingga pada fase ini guru memberikan tugas tentang materi penyusunan laporan keuangan dan memanggil siswa secara acak untuk menyelesaikan penyusunan laporan keuangan yang tersaji pada papan. Setelah siswa yang terpilih mengerjakan soal yang diberikan, guru memberikan pertanyaan secara lisan untuk lebih mengecek pemahaman siswa. Pada fase kelima, yaitu guru memberikan kesempatan untuk pelatihan lanjutan dengan memberikan pekerjaan rumah kepada siswa.

Setelah semua fase pada model pengajaran langsung diterapkan, guru melaksanakan evaluasi pembelajaran untuk mengetahui keefektifan model pengajaran 
langsung pada pembelajaran di siklus kedua. Hasil observasi yang dilaksanakan terhadap guru dalam hal penguasaan kelas dan mengajar adalah sebagai berikut: (1) Guru sudah mulai menciptakan suasana belajar yang santai tapi serius; (2) Bahasa yang digunakan sudah dapat dipahami dengan mudah; (3) Guru sudah mulai mampu memotivasi siswa untuk aktif dalam belajar tetapi belum berhasil; (4) Management waktu perlu ditingkatkan supaya tidak melaksanakan pembelajaran yang terkesan terburu-buru. Hasil observasi yang dilaksanakan oleh guru terhadap siswa adalah sebagai berikut: (1) Siswa sudah fokus terhadap pelajaran sehingga mampu memahami instruksi dari guru; (2) Jumlah siswa yang mengobrol di kelas selama pelajaran berkurang dan sudah tidak ada siswa yang tidur-tiduran.

Hasil dari refleksi yang dilaksanakan pada siklus II adalah sebagai berikut: (1) Guru harus lebih memberi motivasi kepada siswa untuk aktif di kelas; (2) Management waktu perlu diperbaiki; (3) Beberapa siswa menjadi kunci ketenangan kelas; (3) Setelah dilakukan tes hasil belajar pada siklus II diperoleh hasil yang menunjukkan peningkatan yang cukup signifikan, yaitu $75 \%$ atau 24 siswa dari 32 siswa memperoleh nilai di atas KKM (75). Anak yang memperoleh nilai antara 70 - 74 sebanyak lima anak, dan tiga anak lainnya memperoleh nilai antara 60 - 69. Berdasarkan hasil observasi dan refleksi, diketahui bahwa indikator keberhasilan telah terpenuhi sehingga PTK dapat dihentikan. Namun pelaksanaan PTK ini masih terdapat kekurangan yang perlu diperbaiki untuk pembelajaran selanjutnya yang lebih baik.

\section{SIMPULAN}

Penelitian Tindakan Kelas (PTK) di kelas XI Keuangan 2 SMK Negeri 1 Pamekasan dilaksanakan dalam 2 siklus untuk mendapatkan hasil penelitian yang memenuhi indikator keberhasilan. Hasil penelitian menunjukkan bahwa terjadi peningkatan prestasi belajar siswa, dari yang sebelumnya hanya $16 \%$ siswa yang mencapai KKM menjadi 75\% siswa yang mencapai dan melampaui KKM. Jadi, dapat disimpulkan bahwa penerapan model pengajaran langsung dapat meningkatkan prestasi belajar siswa pada mata diklat menyusun laporan keuangan perusahaan dagang pada siswa kelas XI Keuangan 2 SMKN 1 Pamekasan. 


\section{DAFTAR RUJUKAN}

Anonimous.Tanpa tahun. Direct Instruction, (Online),

(http://www.educationbug.org/a/direct-instruction.html,diakses 14 Januari 2012.

Anonimous. 2009. Pengertian Prestasi Belajar, (Online),

(http://sunartombs.wordpress.com/2009/01/05/pengertian-prestasi-belajar/, diakses 14 Januari 2012.

Dzaki, Muhammad Faiq. 2009. Model Pengajaran Langsung (Direct Instruction), (Online),(http://penelitiantindakankelas.blogspot.com/2009/03/modelpengajaran -langsung-direct.html, diakses 14 Januari 2012).

Tim Pelatih Proyek PGSM. 1992. Penelitian Tindakan Kelas. Jakarta: Departemen Pendidikan dan Kebudayaan.

Trianto. 2009. Mendesain Model Pembelajaran Inovatif-Progresif. Surabaya: Kencana.

Wiriaatmadja, Rochiati. 2006. Metode Penelitian Tindakan Kelas. Bandung: Remaja Rosdakarya. 